\title{
Introduction of Gyrodactylus perccotti (Monogenea) into Europe on its invasive fish host, Amur sleeper (Perccottus glenii, Dybowski 1877)
}

\author{
M. ONDRAČKOVÁ ${ }^{1 *}$, I. MATĚJUSOVÁ ${ }^{2}$, J. GRABOWSKA $^{3}$
}

${ }^{1}$ Department of Fish Ecology, Institute of Vertebrate Biology ASCR, v.v.i., Květná 8, 60365 Brno, Czech Republic,
E-mail: audrey@sci.muni.cz; ${ }^{2}$ Marine Scotland Marine Laboratory, P.O. Box 101, Aberdeen, AB11 9DB, United
Kingdom; ${ }^{3}$ Department of Ecology and Vertebrate Zoology, University of Lodz, Banacha 12/16, 90-237 Lodz, Poland

\begin{abstract}
Summary
Monogenean parasites of Amur sleeper Perccottus glenii introduced to Europe during the last century were studied during two seasons in the Wloclawski Reservoir (Poland). Introduction of a single species Gyrodactylus perccotti with its host was confirmed in both seasons: autumn 2006 and spring 2008. Occurrence of G. perccotti in Europe was reported for the first time. Intensity of infection decreased from 2006 to 2008, but the prevalence did not differ between the seasons. G. perccotti sampled in autumn 2006 showed low morphometrical variability and high morphological similarity with parasites collected in host native range, Amur River. In contrary, high morphological and metrical variability was found within the samples collected in spring 2008. Nucleic acid sequencing of the partial ITS rDNA confirmed that despite the variation in morphology or size of haptoral hard parts, all studied Gyrodactylus specimens belonged to the same species $(G$. percotti) and no intraspecific variation was detected.
\end{abstract}

Keywords: Amur sleeper; Monogenea; Gyrodactylidae; species introduction

\section{Introduction}

Native area of Amur sleeper, Perccottus glenii Dybowski, 1877 (Odontobutidae), distribution covers the Far East of Russia, north-east China and northern North Korea (Bogutskaya \& Naseka, 2002). Several time during 1990's, $P$. glenii either escaped from pet shops or was accidentally released (as a bait fish) into the open waters in European part of the former Soviet Union. The fish survived, acclimatized and further naturally dispersed to many adjacent countries (Reshetnikov, 2004). To date, Amur sleeper has been reported as a non-native fish species in several European countries (summarized in Reshetnikov, 2004) and consequently been included in the Bern Convention on the conservation of European wildlife and natural habitats as an alien species.

In Poland, this fish was recorded for the first time in 1993 (in oxbow lake of the Vistula River near Dęblin) (Antychowicz, 1994), and in a short period its population rapidly expanded and fish migrated downstream of the Vistula River and its tributaries (Nowak et al., 2008). There is no evidence or record of fish release directly linked to $P$. glenii presence in Poland and the circumstances of its introduction to Poland remain unclear (Grabowska et al., 2010).

To date, occurrence of two parasite species of Amur sleeper was reported in Europe: cestode parasite Nippotaenia (syn. Amurotaenia) mogurndae found in the Latorica River (Slovakia) (Košuthová et al., 2009) and Wloclawski Reservoir (Poland) (Mierzejewska et al., 2009) and nematode parasite Eustrongylides sp., which larval stages infect percid and gobiid fish as intermediate or paratenic hosts, found in Danube River (Serbia) (Nikolic et al., 2007; Moravec, 2008). Whilst $N$. mogurndae is a parasite native to the Far-East region and was introduced with its fish to Europe (Košuthová et al., 2004), larvae of eustrongylid nematodes are common in various taxa of poikilothermic animals inhabiting European waters (Moravec, 1994) and colonized the Amur sleeper as a new host species.

During our parasitological investigation of non-native fish in the Vistula River (Poland), monogenean parasites belonging to the genus Gyrodactylus were found infecting fins and opercula of P. glenii. Species of Gyrodactylus are common ectoparasites of fish in Eurasian fresh and salt waters (Harris et al., 2004). Species determination within the genus Gyrodactylus is based upon subtle differences in morphology of the haptoral hard parts (i.e. anchors, marginal hooks and ventral bar) (Malmberg, 1970). However, factors like water temperature, host size or geographical location were identified affecting the intraspecific phenotypic variation of the haptoral hard parts. Therefore, both morphometrical characters of haptoral hard parts and molecular data are currently recommended to be the most 
reliable method for diagnostics of Gyrodactylus species (Bakke et al., 2007). Using morphology of the haptoral hard parts, parasites found in the present study closely resembled those of Gyrodactylus perccotti (Ergens \& Jukhimenko, 1973) described from P. glenii in the Amur River (Russia). The present study describes presence of $G$. perccotti in its non-native area of distribution during two seasons and also investigates its morphological and molecular variations. The internal transcribed spacer was selected for sequencing as this region was shown as a species marker with the potential to distinguish closely related species (e.g. Matějusová et al., 2001; Huyse \& Volckaert, 2002; Zietara \& Lumme, 2003).

\section{Materials and methods}

\section{Parasite collection}

Host fish, Amur sleeper, were sampled by electrofishing in the Wloclawski Reservoir (the lower part of the Vistula River, Poland, near the Soczewka village (N52 32 ' 58'; E19 34' 29"). During September 2006 (water temperature $18{ }^{\circ} \mathrm{C}$ ) and April 2008 (w.t. $12{ }^{\circ} \mathrm{C}$ ), 15 fish individuals (SL: 65.9 - $106.3 \mathrm{~mm}$; mean: $82.6 \pm 10.0$ S.D.) and 27 fish individuals (SL: $35.8-115.5 \mathrm{~mm}$; mean: $66.4 \pm 22.0$ S.D.) for further morphological and morphometric analyses. The remaining part of a body was stored in $96 \%$ ethanol at $4{ }^{\circ} \mathrm{C}$ prior to molecular analyses.

\section{Morphometric analyses}

Parasite identification and analysis of the haptoral hard parts were performed using a light microscope (Olympus BX51) equipped with a phase-contrast and differential interference contrast (DIC). Drawings of haptoral hard structures were made with the aid of a drawing attachment and phase-contrast optics. Twenty-two and thirty individuals of $G$. perccotti from 2006 and 2008 respectively were selected for analysis of intraspecific variability of the haptoral hard parts. The type material of $G$. perccotti including six specimens collected from $P$. glenii in the native area of distribution (the Amur River near Khabarovsk, Russia, May 1968) were obtained from the Helminth Collection, Institute of Parasitology, Academy of Sciences of the Czech Republic (N-46-1, Coll. No. M-139) for comparison. According to Winger et al. (2008), sixteen morphological characters on anchor, dorsal and ventral bars and marginal hook $(\mathrm{MH})$ were measured to the nearest micrometer (Table 1).

Table 1. Measurements (in $\mu \mathrm{m}$; mean, range in parentheses) of the haptoral hard parts of $G$. perccotti from the native (type-material from Amur River, Russia) and non-native (Wloclawski Reservoir, Poland) area of distribution

\begin{tabular}{lccc}
\hline & Amur river & \multicolumn{2}{c}{ Wloclawski reservoir } \\
& $\mathbf{1 9 6 8}$ & $\mathbf{2 0 0 6}$ & $\mathbf{2 0 0 8}$ \\
\hline Nnchor & $\mathbf{6}$ & $\mathbf{2 2}$ & $\mathbf{3 0}$ \\
$\quad$ Total length & & & \\
Shaft length & $83.4(81.5-84.9)$ & $80.7(76.4-83.7)$ & $79.5(72.4-84.6)$ \\
Root length & $56.2(55.3-56.9)$ & $52.9(46.8-55.0)$ & $53.9(48.3-59.8)$ \\
$\quad$ Point length & $36.8(34.7-39.8)$ & $37.2(33.7-39.8)$ & $34.8(28.8-40.1)$ \\
Ventral bar & $34.6(33.6-35.3)$ & $34.6(32.9-36.5)$ & $35.8(34.0-38.0)$ \\
$\quad$ Total length & & & \\
Total basal width & $26.4(23.2-28.8)$ & $25.1(23.1-28.4)$ & $23.6(21.6-26.6)$ \\
Median width & $34.0(33.0-34.9)$ & $34.1(26.0-39.3)$ & $32.4(25.9-36.0)$ \\
Membrane length & $10.9(8.5-13.3)$ & $10.0(7.7-12.9)$ & $10.3(7.7-13.6)$ \\
Dorsal bar & $19.0(18.9-19.1)$ & $19.4(14.1-24.5)$ & $18.7(16.4-21.4)$ \\
Total width & & & \\
Total length & $21.0(18.2-23.8)$ & $18.0(14.2-21.1)$ & $16.4(11.8-22.2)$ \\
Marginal hook & $2.1(1.3-3.0)$ & $2.3(1.7-2.9)$ & $2.2(1.5-2.8)$ \\
$\quad$ Total length & & & \\
Handle length & $34.7(33.6-35.4)$ & $33.1(31.2-35.1)$ & $36.0(32.0-37.8)$ \\
Sickle length & $24.1(22.7-25.2)$ & $22.7(21.1-24.3)$ & $25.1(21.6-27.2)$ \\
Aperture distance & $11.2(10.0-12.1)$ & $11.4(10.4-12.3)$ & $11.6(10.1-12.7)$ \\
Sickle toe width & $10.5(10.1-10.8)$ & $10.4(9.5-11.6)$ & $10.4(9.3-11.9)$ \\
Sickle proximal width & $3.3(2.8-3.4)$ & $3.0(2.7-3.8)$ & $3.2(2.6-3.8)$ \\
& $6.8(6.5-7.0)$ & $6.9(6.3-7.2)$ & $7.5(6.6-8.4)$ \\
\hline
\end{tabular}

were collected, respectively. Fish were transported in the original river water in aerated tanks to the laboratory, sacrificed and fins, gills and body surface were examined for the presence of parasites. Gyrodactylid parasites were removed and transferred into a drop of water on a microscope slide. The haptor was excised and fixed with a mixture of ammonium picrate and glycerine (Malmberg, 1970)
Molecular analyses

Genomic DNA was extracted from $G$. perccotti individuals according the method described in Matějusová et al. (2001). The ITS region was amplified using primers ITS1 and ITS2 (Cunningham, 1997) subjected to 35 cycles of $95{ }^{\circ} \mathrm{C}$ for $1 \mathrm{~min}, 55^{\circ} \mathrm{C}$ for $1 \mathrm{~min}$ and $72{ }^{\circ} \mathrm{C}$ for $1 \mathrm{~min} 30$ sec. The PCR products were purified from agarose gel 
(MinElute, Qiagen) and sequenced in both directions using the same primers as in the amplification reaction. Sequencing was carried out using GenomeLab DTCS Quick Start kit and CEQ8800 DNA Sequencer (Beckman Coulter). Partial ITS sequences were analysed in Sequencher software (Gene Codes Corp.). Sequences were aligned using CLUSTAL $\mathrm{W}$ implemented in BioEdit 7.0.9.0 (Hall, 1999).

\section{Data analyses}

Prevalence, abundance and intensity of parasite infection were calculated according to Bush et al. (1997). $\chi^{2}$ test was used to investigate differences in prevalence, and MannWhitney $U$ test was used to compare the intensity of infection between the seasons. The relationship between fish length and intensity of $G$. perccotti infection was tested by Spearman rank correlation test. Principal component analysis (PCA) was used to visualize the position of G. perccotti specimens from native and introduced area of distribution in morphological space according to Dávidová et al. (2005) applying measurements of eight morphological characters. Measurements with non-homogenous variance (incomplete data sets) such as anchor shaft length and sickle proximal width of marginal hook, and ventral and dorsal bar size were excluded from the PCA analysis. First and second factorial axis were adopted for subsequent analysis of differences among samples based on a single parasite characteristic using One-way Analysis of variance followed by Tukey Post-hoc test for multiple comparisons. Statistical analyses were performed using Statistica 9.1 (StatSoft, Inc).

\section{Results}

\section{Epidemiology of G. perccotti}

Gyrodactylus perccotti was recorded in both seasons. In autumn 2006, the prevalence was $93.3 \%$, mean abundance 5.8 , and intensity of infection ranged from 2 to 12 parasites per fish. In spring 2008, prevalence of G. perccotti infection was $77.8 \%$, mean abundance 2.7 , and the range of parasite intensity of infection was $1-17$ parasites per fish. There was no significant difference in prevalence between the seasons (chi test, $p>0.05$ ). However, the intensity of infection was significantly higher in autumn 2006 (MWU, $Z=3.07, p=0.002$ ). Majority of parasites were found on fins (97.7 \% and $80 \%$ in 2006 and 2008, respectively) and the remaining parasites harboured the fish opercula. There was no significant relationship between the fish host size and intensity of parasite infection (Spearman rank correlation, $p>0.05$ for both seasons).

\section{Morphological and metrical variability}

Measurements of $G$. perccotti haptoral hard parts from the Wloclawski Reservoir and paratypes from the Amur River are given in Table 1. Morphological variability of anchor and marginal hook are shown in Fig. 1. Parasite individuals collected in autumn 2006 (Fig. 1B) showed a low variability in morphology of anchors and marginal hooks and closely resembled those parasites from the original description (Fig. 1A), compared to a high variability in specimens collected in spring 2008 (Fig. 1C).

To investigate differences in morphometric characters among the three groups (type material spring 1968, autumn 2006 and spring 2008), a PCA analysis was performed. The first two axes (PC1 and PC2) explained $33 \%$ and $22 \%$ of the overall morphological variability, respectively. The PC1 and PC2 scores are graphically visualized on Fig. 2. PC1 was influenced mainly by the measurements of anchor point, total and handle length of $\mathrm{MH}$, and $\mathrm{MH}$ sickle toe width. The scores significantly differed between the spring 2008 individuals and other two samples $\left(F_{(2,48)}=\right.$ $30.8, p<0.001)$. PC2 was influenced by total anchor length and marginal hook aperture distance; and the scores significantly differed between the autumn 2006 and spring $2008\left(F_{(2,48)}=4.3, p=0.019\right)$.

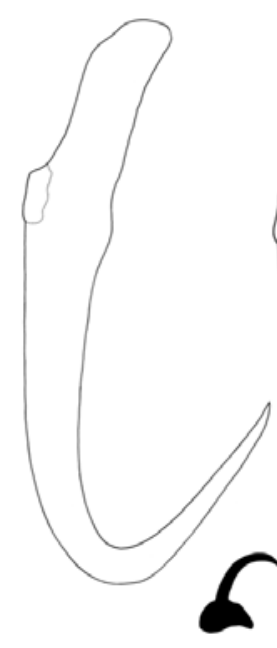

A

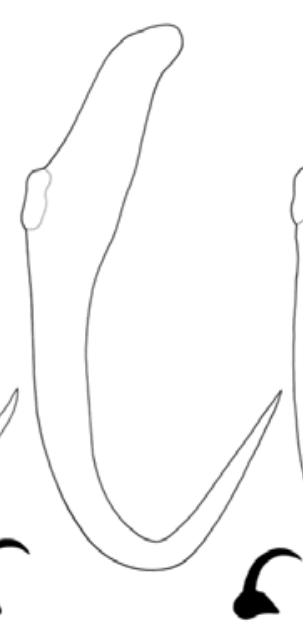

$\mathrm{B}$

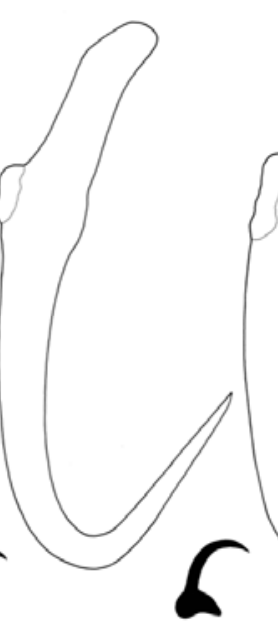

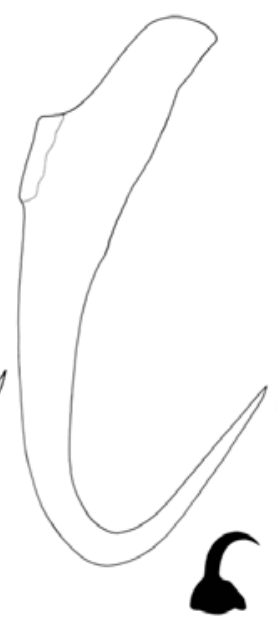

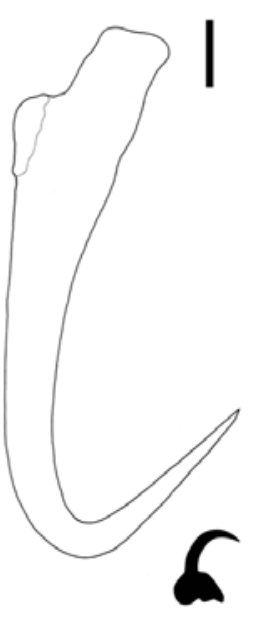

C

Fig. 1. Morphological variability of haptoral hard parts (anchors, marginal hooks) of G. perccotti in the Amur River (A), and Wloclawski Reservoir during autumn 2006 (B) and spring 2008 (C) sampling periods. Scale-bar: $10 \mu \mathrm{m}$. A - Amur River, May 1968; B - Wloclawski Reservoir, September 2006; C - Wloclawski Reservoir, April 2008 


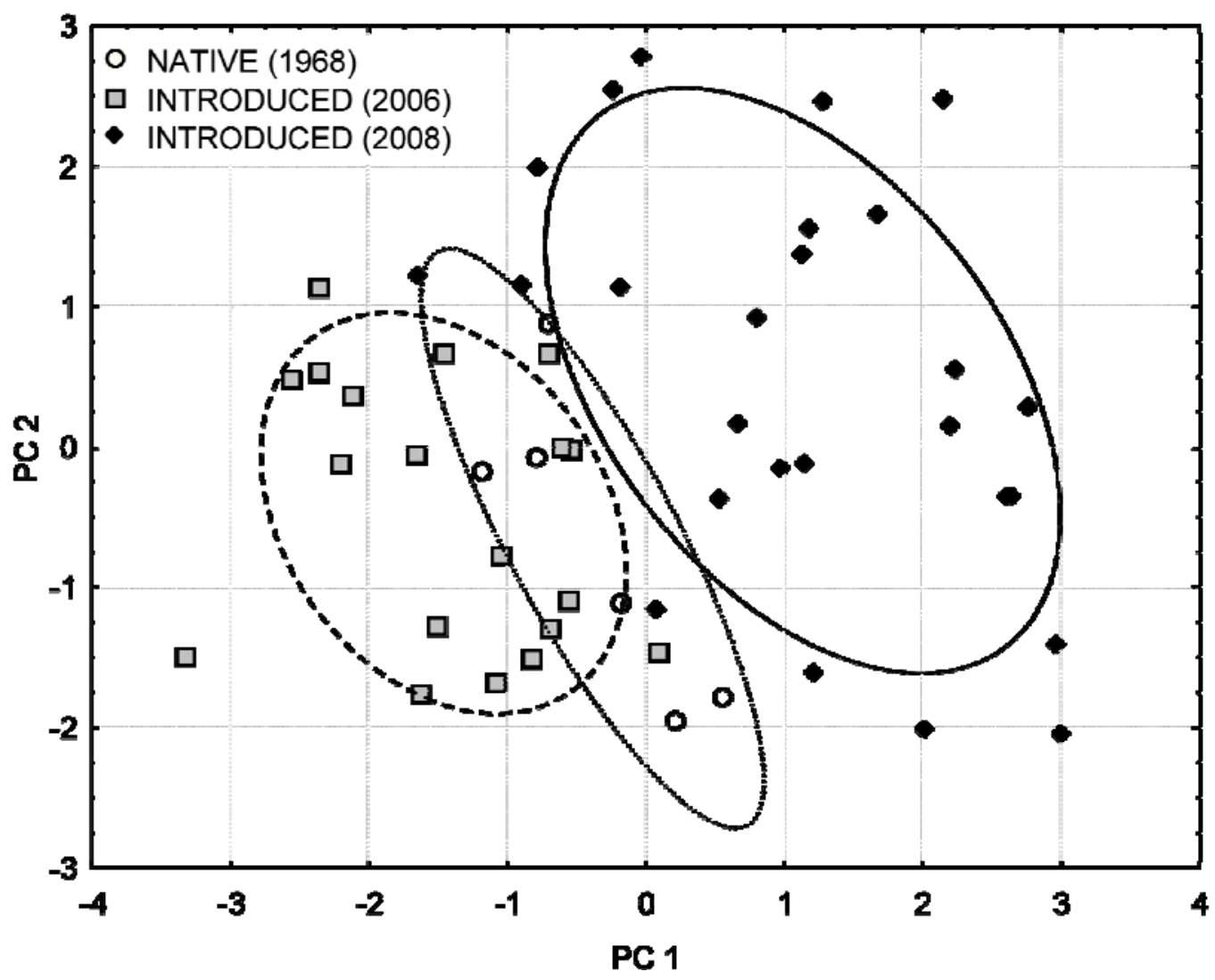

Fig. 2. Principal component analysis on the morphological measurements of $G$. perccotti from the native region (Amur River, former Soviet Union) and range of introduction (Wloclawski Reservoir, Poland) during two seasons

\section{Molecular analyses}

The amplified ITS fragment was 944 bp long and consisted of the SSU (32 bp), the internal transcribed spacers (ITS) 1 spacer (343 bp), the 5.8S gene (157 bp), ITS 2 spacer (352 $\mathrm{bp})$ and the LSU (60 bp). All sequences from 11 individuals - sample 2006, and 10 individuals - sample 2008 (including all three morphological types, see Fig. 1C) were identical. A BLASTN search (Altschul et al., 1997) of the obtained nucleotide sequences revealed no identical hits with entries in Gene Bank. Nucleotide sequences obtained in the present study were deposited in Gene Bank with the accession number JN603638.

\section{Discussion}

Amur sleeper, $P$. glenii, is reported as a non-native (alien) species in many European countries (Reshetnikov, 2004; Grabowska et al., 2010). Parasite fauna of the Amur sleeper was extensively investigated in many geographic regions of the Danube River basin, including the Danube River (Serbia) (Nikolic et al., 2007), Tisza River (Slovakia) (Košuthová et al., 2009) and Latorica River (Slovakia) (Ondračková, unpublished data), with no monogenean parasites found to date. The present study represents the first occurrence of $G$. perccotti, a parasite introduced with its fish host, in Europe. According to previous studies, the occurrence of this parasite in Europe appears to be restricted only to the Vistula River basin. These findings might suggest that the introduction of Amur sleeper to different river systems (Vistula vs. Danube River basins) might be result of separate introduction events or that the original population of fish and/or parasites was too small to maintain and establish a stable Gyrodactylus population. As for the Danube introduction (Reshetnikov, 2004), events related to the Amur sleeper introduction to Poland also remain unknown (Grabowska et al., 2010).

There are two Gyrodactylus species known from P. glenii in its native area of distribution: G. perccotti and Gyrodactylus glehnii (Ergens \& Jukhimenko, 1973). Both parasite species were found in the Amur River, Khanka Lake and rivers in Primorye region, Russia (see Ermolenko, 2003). Investigations of the Amur sleeper parasites in those geographic regions showed a higher abundance of G. perccotti when compared to the scarce occurrence of G. glehnii (Ergens \& Jukhimenko, 1973; Ermolenko, 2003). It has been suggested that during the process of introduction, host species loose about half of the parasite species richness associated with their native area (Torchin et al., 2003). Higher abundances of particular species in the native range of its host may indicate higher probability of successful introduction with the host, especially in those parasites which do not require an intermediate host for completion of their life cycle. Occurrence of a single species $G$. perccotti in Europe may therefore be a consequence of the potential parasite loss during an introduction process coupled to the low abundances of $G$. glehnii in its native area of origin. 
Most of gyrodactylids infect the skin and fins, while only few species were reported inhabiting gills. In some species, a site selection occurs as a consequence of an increase in intensity of infection, differences in water temperature or salinity. In literature, there are examples when gyrodactylids of the same species harbouring gill and fins respectively, were misidentified as members of two distinct species (Bakke et al., 2007). All gyrodactylids in the present study were found on fins and opercula while both species of Gyrodactylus collected in the River Amur were found on gill filaments (Ergens \& Jukhimenko, 1973). We believe that the difference in parasite habitat should not be the decisive factor for an existence of a new species and despite some differences in morphology of the original material and parasites collected in 2008, all individual from the present study were identified as G. percotti.

In addition, a variable region of ribosomal DNA (ITS), was sequenced for individuals from samples collected during autumn 2006 and 2008. Results showed no intraspecific variability among sequenced individuals, including individuals demonstrating a high morphological variability as illustrated on Figure 1C. This result was quite surprising given the observed variability mainly in the shape of marginal hooks. We were unable to obtain genetic data for $G$. perccotti from the original description and therefore the species identification of the present material relies on the morphological similarity of the haptoral hard parts. This hypothesis could only be confirmed or rejected when the original material become available for DNA analysis.

Variation in the size of gyrodactylid haptoral hooks is usually related to seasonal changes in water temperature. Specimens with larger hooks occur typically in months with lower temperatures (e.g. Appleby, 1994; Dávidová et $a l ., 2005$ ) and vice versa. Differences in the shape of haptoral hard parts among individual of the same species are also often reported and again various abiotic factors are suggested as the main causes (Dimitreva \& Dimitrov, 2002; Dávidová et al., 2005). In addition, also differences in a host species might influence haptoral morphology of Gyrodactylus as reported by several authors (Huyse \& Volckaert, 2002; Robertsen et al., 2007). The present study showed that measurements of almost all haptoral hard parts of G. perccotti collected in the Wloclawski Reservoir were comparable to those from the original description (Ergens \& Jukhimenko, 1973). However, the ranges in introduced parasites were greater, most likely as a result of the larger sample size. In addition, some differences in measurements were found between both the areas of origin (e.g. smaller size of anchor shaft length in the area of introduction) and seasons (e.g. larger total length of marginal hook in spring 2008, Table 1). When using information from all measured characteristics of the parasite haptoral hard parts applying a multivariate analysis, such as PCA (Shinn et al., 2001; Huyse \& Volckaert, 2002; Dávidová et al., 2005), a good separation was demonstrated between the non-native population of $G$. perccotti from spring 2008 and the both the non-native 2006 material and archived type material. However, it was not clear if the differences in the area of origin or differences in the water temperature attributed to the observed variation of $G$. percotti haptoral hard parts. In the present study, we confirm the introduction of $G$. perccotti, a parasite species native to the Amur region, into the Wloclawski Reservoir (Vistula River, Poland) on its non-native host species, $P$. glenii. To date, there is no record of $G$. perccotti parasitizing other host species either in its native or non-native area of distribution. This might suggests its narrow host specificity and indicate potentially a low risk of transmission to a new host. However, further investigations are required to confirm this hypothesis as a process of host switching is quite common for Gyrodactylus parasites (Huyse \& Volckaert, 2005). Because of the direct life cycle, asexual reproduction and no specialized transmission stage, gyrodactylids play an important role as pathogens in fish farms and aquacultures, and introduction of new non-native parasites always posses threat to aquaculture and wild fish population as demonstrated in the case of Gyrodactylus salaris (e.g. Bakke et al., 1992; Johnsen \& Jensen, 1999).

\section{Acknowledgement}

This study was supported by Ichthyoparasitology Research Centre, No. LC 522. We would like to thank the Polish Angling Association (PZW) for sampling permission, Miroslaw Przybylski, Dariusz Pietraszewski, Lukasz Kapusta and Szymon Tybulczuk) for help with fish sampling, and colleagues from the Faculty of Science, Masaryk University Brno (Czech Republic) for help with parasite collection.

\section{References}

APPlEBY, C. (1994): Gyrodactylus (Platyhelminthes: Monogenea) infesting Atlantic cod, Gadus morhua L. Bull. Scand. Soc. Parasitol., 4: 23 - 32

ANTYCHOWICZ, J. (1994): Perccottus glehni in our waters. Komunikaty Rybackie, 2: 21 - 22 (in Polish)

Bakke, T. A., Harris, P. D., Jansen, P. A., Hansen, L. P. (1992): Host specificity and dispersal strategy in gyrodactylid monogeneans, with particular reference to Gyrodactylus salaris (Platyhelminthes, Monogenea). Dis. Aquat. Org., 13: 63 - 74

BAKKe, T. A., CABle, J., Harris, P. D. (2007): The biology of gyrodactylid monogeneans: The "Russian - doll killers". Adv. Parasitol., 64: 161 - 378. DOI:10.1016/S0065-308X(06)64003-7

Bogutskaya, N. G., NAseKA, A. M. (2002): Perccottus glenii Dybowski, 1877. In: Freshwater fishes of Russia. Zoological Institute RAS. http:/www.zin.ru/Animalia/ Pisces/eng/taxbase_e/species_e/perccottus/perccottus_glen ii_eng.pdf

Búsh, A. O., Lafferty, K. D., Lotz, J. M., Shostak, A. W. (1997): Parasitology meets ecology on its own terms: Margolis et al. Revisited. J. Parasitol., 83: 575 - 583

Cunningham, C. O. (1997): Species variation within the internal transcribed spacer (ITS) region of Gyrodactylus 
(Monogenea: Gyrodactylidae) ribosomal RNA genes. $J$. Parasitol., 83: 215 - 219

DÁvidOVÁ, M., JARKOVSKÝ, J., MATĚJusovÁ, I., GELNAR, M. (2005): Seasonal occurrence and metrical variability of Gyrodactylus rhodei Žitňan 1964 (Monogenea, Gyrodactylidae). Parasitol. Res., 95: 398 - 405. DOI: 10.1007/s00436-005-1311-0

Dimitreva, E., Dimitrov, G. (2002): Variability in the taxonomic characters of Black Sea gyrodactylids (Monogenea). Syst. Parasitol., 23: $111-126$

ERGENS, R., JukHimenko, C. C. (1973): Two new species of Gyrodactylus Nodrmann (Monogenoidea) from Perccottus glehni. Parazitologyia, 7: 186 - 188

ERmolenko, A. V. (2004): Parasite fauna of Amur sleeper Perccottus glehni (Elotridae). Parazitologiya, 3: 251 - 256 Geets, A., Appleby, C., Ollevier, F. (1999): Hostdependent and seasonal variation in opisthaptoral hard parts of Gyrodactylus cf. arcuatus from free Pomatoschistus spp. and G. arcuatus from Gasterosteus aculeatus: a multivariate approach. Parasitology, 119: 27 - 40

Grabowska, J., Kotusz, J., WitKowski, A. (2010): Alien invasive fish species in Polish waters: an overview. Folia Zool., 59: $73-85$

HALL, T. A. (1999): BioEdit: A user friendly biological sequence alignment editor and analysis program for Windows 95/98/NT. Nucleid Acids Symp. Ser., 41: 95 - 98 HARRIS, P. D. (1998): Extreme morphological variation between related individuals of Gyrodactylus pungitii Malmerg, 1964 (Monogenea). Syst. Parasitol., 39: 137 - 140 Harris, P. D., Shinn, A. P., CABle, J., BAKke, T. A. (2004): Nominal species of the genus Gyrodactylus von Nordmann 1832 (Monogenea: Gyrodactylidae), with a list of principal host species. Syst. Parasitol., 29: $1-27$

HuYse, T., VOLCKAERT, F. A. M. (2002): Identification of a host-associated species complex using molecular and morphometric analyses, with the description of Gyrodactylus rugiensoides n. sp. (Gyrodactylidae, Monogenea). Int. J. Parasitol., 32: 907 - 919. DOI: 10.1016/S0020-7519(02)00026-7

Huyse, T., Volckaert, F. A. M. (2005): Comparing Host and Parasite Phylogenies: Gyrodactylus Flatworms Jumping from Goby to Goby. Syst. Biol., 54: 710 - 718 JoHnSEN, B. O., JENSEN, A. J. (1991): The Gyrodactylus story in Norway. Aquacult., 98: 289 - 302

KošUthová, L., Koščo, J., LetKová, V., KoŠUth, P., MANKo, P. (2009): New records of endoparasitic helminths in alien invasive fishes from the Carpathian region. Biológia, 64: 776 - 780

MALmberG, G. (1970): The excretory systems and the marginal hooks as a basis for the systematics of Gyrodactylus (Trematoda, Monogenea). Ark. Zool., 23 :1 - 235
MatěJusová, I., Gelnar, M., McBeath. A. J. A., Collins, C. M., Cunningham, C. O. (2001): Molecular markers for gyrodactylids (Gyrodactylidae: Monogenea) from five fish families (Teleostei). Int. J. Parasitol., 31: 738 - 745. DOI: 10.1016/S0020-7519(01)00176-X

MierzeJEWSKA, K., MartyniaK, A., KaKareKo, T., AIWA, P. (2009): First record of Nippotaenia mogurndae Yamaguti and Miyata, 1940 (Cestoda, Nippotaeniidae), a parasite introduced with Chinese sleeper to Poland. Parasitol. Res., 106: 451 - 456. DOI: 10.1007/s00436009-1685-5

MoraVeC, F. (1994): Parasitic Nematodes of Freshwater Fishes of Europe. Academia, Praha, Czech Republic, 473 pp.

MORAVEC, F. (2008): Mididentification of nematodes from the Chinese sleeper Perccottus glenii in Europe. Bull. Eur. Ass. Fish Pathol., 28: 86 - 87

NiKOLIC, V. (2007): First record in Europe of a nematode parasite in Amur sleeper Perccottus glenii Dybowski, 1877 (Perciformes: Odontobutidae). Bull. Eur. Ass. Fish Pathol., 27: 36

Nowak, M., PopeK, W., EPler, P. (2008): Range expansion of an invasive alien species, Chinese sleeper, Perccottus glenii Dybowski, 1877 (Teleostei: Odontobutidae) in the Vistula River drainage. Acta Ichthyol. Pisc. 38: 37 - 40 Reshetnikov, A. N. (2004): The fish Perccottus glenii: history of introduction to western regions of Eurasia. Hydrobiologia, 522: 349 - 350

Robertsen, G., Hansen, H., Bachmann, L., Bakke, T. A. (2007): Arctic charr (Salvelinus alpinus) is a suitable host for Gyrodactylus salaris (Monogenea, Gyrodactylidae) in Norway. Parasitology, 134: 257 - 267. DOI: 10.1017/S0031182006001223

Shinn, A. P., Gibson, D. I., Sommerville, C. (2001): Morphometric discrimination of Gyrodactylus salaris Malmberg (Monogenea) from species of Gyrodactylus parasitizing British salmonids using novel parameters. J. Fish Dis., 24: 83 - 97. DOI: 10.1046/j.1365-2761.2001.00272.x

Torchin, M. E., LAfFerty, K. D., Dobson, A. P., MCKenZIE, V. J., KURIS, A. M. (2003): Introduced species and their missing parasites. Nature, 421: 628 - 630. DOI: 10.1038 /nature 01346

Winger, A. C., Hansen, H., Bachmann, L., BaKke, T. A. (2005): Gyrodactylus species (Monogenea) infecting alpine bullhead (Cottus poecilopus Heckel, 1837) in Norway and Slovakia, including the description of Gyrodactylus mariannae sp. nov. Acta Parasitol., 53: 240 - 250. DOI: $10.2478 / \mathrm{s} 11686-008-0045-4$

ZieTARA, M. S., LuMme, J. (2003): The crossroads of molecular, typological and biological species concepts: two new species of Gyrodactylus Nodmann, 1832 (Monogenea: Gyrodactylidae). Syst. Parasitol., 55: 39 - 52 